\title{
Interactions of Pseudomonas syringae pv. glycinea with Host and Nonhost Plants in Relation to Temperature and Phytotoxin Synthesis
}

\author{
Ina P. Budde and Matthias S. Ullrich \\ Max-Planck-Institut für terrestrische Mikrobiologie, AG Ökophysiologie, Karl-von-Frisch-Strasse, \\ 35043 Marburg, Germany \\ Accepted 11 May 2000.
}

Pseudomonas syringae pv. glycinea PG4180 causes bacterial blight of soybean and produces the phytotoxin coronatine (COR) in a temperature-dependent manner. COR consists of a polyketide, coronafacic acid (CFA), and an amino acid derivative, coronamic acid, and is produced optimally at $18^{\circ} \mathrm{C}$ whereas no detectable synthesis occurs at $28^{\circ} \mathrm{C}$. We investigated the impact of temperature on PG4180 during compatible and incompatible interactions with soybean and tobacco plants, respectively. After spray inoculation, PG4180 caused typical bacterial blight symptoms on soybean plants when the bacteria were grown at $18^{\circ} \mathrm{C}$ prior to inoculation but not when derived from cultures grown at $28^{\circ} \mathrm{C}$. The disease outcome was quantified by determination of bacterial populations in planta. The temperature effect was not observed when PG4180 was artificially infiltrated into soybean leaves, indicating that the pre-inoculation temperature and phytotoxin synthesis were important for bacterial invasion via natural plant openings. In the incompatible interaction, PG4180 elicited the hypersensitive response (HR) on tobacco plants regardless of the bacterial pre-inoculation temperature. However, the HR was significantly delayed when tobacco plants were treated with cells of the CFA-overproducing derivative, PG4180.N9, which were derived from cultures grown at $18^{\circ} \mathrm{C}$, compared with parallels incubated at $28^{\circ} \mathrm{C}$. CFA biosynthesis by PG4180.N9 was optimal at $18^{\circ} \mathrm{C}$ and negligible at $28^{\circ} \mathrm{C}$. The impact of CFA synthesis on the HR was studied with different growth media, mutants, and transconjugants of PG4180, indicating that the amount of synthesized CFA but not that of COR influenced the outcome of the HR. Feeding experiments with purified coronafacoyl compounds suggested that the observed delay of the HR was mediated by CFA, shedding further light on CFA's putative role as a molecular mimic of the plant signaling molecule, jasmonic acid.

Plant-pathogenic bacteria are subject to numerous environmental stimuli during infection processes, and it has been well established that temperature can have a major impact on plant

Corresponding author: Matthias S. Ullrich

Telephone: (+49) 6421 178101; Fax: (+49) 6421178109

E-mail: ullrichm@mailer.uni-marburg.de disease outcome. However, in contrast to our understanding of thermoregulation in pathogenic bacteria of human or animal hosts, little is known about how temperature influences cellular processes in plant pathogens ultimately leading to virulence and pathogenicity. Previous reports showed that the synthesis of virulence factors in Agrobacterium tumefaciens, Pseudomonas syringae pvs. phaseolicola and glycinea, Erwinia chrysanthemi, and Erwinia carotovora was thermoresponsive (Lanham et al. 1991; Hugovieux-Cotte-Pattat et al. 1992; Jin et al. 1993; Rowley et al. 1993; Palmer and Bender 1993; Budde et al. 1998). In all of these cases, low temperature was conducive to virulence factor synthesis, which agrees with the etiology of the diseases incited by these bacteria.

In the compatible interaction, $P$. syringae pv. glycinea PG4180 causes bacterial blight of soybean plants and symptoms are water-soaked lesions that develop into necrotic leaf spots surrounded by chlorotic halos. Low temperature and high humidity can favor bacterial blight infection and disease outcome (Dunleavy 1988). P. syringae pv. glycinea and the closely related pathovars atropurpurea, morsprunorum, maculicola, and tomato produce the non-host-specific polyketide phytotoxin coronatine (COR; Fig. 1) (Mitchell 1982; Bender et al. 1993; Wiebe and Campbell 1993). COR is an important virulence factor in diseases caused by these bacteria. As shown by mutant analysis, COR production enhanced the virulence of $P$. syringae strains on tomato plants, Arabidopsis thaliana, and Chinese cabbage plants (Bender et al. 1987; Mittal and Davis 1995; Tamura et al. 1998).

The biological effects of COR include the induction of leaf chlorosis, promotion of senescence in tobacco (Kenyon and Turner 1990), hypertrophy of potato tuber tissue (Sakai et al. 1979), inhibition of root growth in wheat (Sakai 1980), stimulation of stomatal opening in ryegrass, ethylene synthesis in tobacco, and the synthesis of proteinase inhibitors in tomato (Mino et al. 1987; Ferguson and Mitchell 1985; Kenyon and Turner 1992; Palmer and Bender 1995).

In $P$. syringae pv. glycinea PG4180, all enzymes involved in COR biosynthesis are encoded by the plasmid-borne, 32.8-kb COR gene cluster, which can be subdivided into two biosynthetic operons and three regulatory genes (Ullrich and Bender 1994; Liyanage et al. 1995; Ullrich et al. 1995; Rangaswamy et al. 1998a, 1998b; Fig. 2). Production of COR by PG4180 is maximal at $18^{\circ} \mathrm{C}$ whereas no toxin formation can be detected at $28^{\circ} \mathrm{C}$, the optimal growth temperature of $P$. syringae 
(Palmer and Bender 1993; Ullrich et al. 1995; Budde et al. 1998). The temperature dependence was mediated at the transcriptional level by a modified two-component regulatory system consisting of the environmental sensor kinase, CorS, and two response regulator proteins, CorR and CorP (Ullrich et al. 1995; Penaloza-Vazquez and Bender 1998; Wang et al. 1999). PG4180 does not produce COR when grown in complex medium (Palmer and Bender 1993), a feature frequently observed for synthesis of secondary metabolites in plant pathogenic bacteria.

COR consists of two moieties, coronafacic acid (CFA; Fig. $1)$, which is derived from the polyketide pathway, and coronamic acid (CMA), a cyclized derivative of isoleucine. Both CFA and CMA function as intermediates in the biosynthesis of COR and are joined together by an amide bond linkage. Like the production of COR, the synthesis of CFA and CMA is temperature dependent, with maximal levels produced at $18^{\circ} \mathrm{C}$. CMA structurally resembles 1 -aminocyclopropane- 1 carboxylic acid (ACC), which is a precursor in the ethylene biosynthetic pathway. This encouraged previous speculations that CMA might modulate plant-borne ethylene biosynthesis (Kenyon and Turner 1992).

CFA structurally resembles the global plant signaling molecule jasmonic acid (JA; Fig. 1). JA accelerates senescence and chlorophyll degradation and induces ethylene synthesis in various plants (Sembdner and Parthier 1993). At lower concentrations, JA functions as signal transducer in plant defense against herbivore or pathogen attack (Farmer and Ryan 1990; Reymond and Farmer 1998) and is involved in mechanotransduction (Weiler 1997; Blechert et al. 1999). CFA and JA had similar biological activities when tested in JA-responsive assays (Koda et al. 1996). COR was effective in these assays with activities 100 to 10,000 times higher than those of JA or CFA. Weiler et al. (1994) pointed out that COR should not be regarded as a structural analogue of JA or methyl jasmonate (MeJA) because the position of the essential carboxyl group of COR relative to the cyclopentyl ring is different from that in JA (Fig. 1). Interestingly, COR shares significant structural and functional characteristics with 12-oxophytodienoic acid (OPDA; Fig. 1), an intermediate in JA biosynthesis that was recently associated with a number of regulatory mechanisms in plant defense (Dittrich et al. 1992; Weiler 1997; Zhang et al. 1997). This suggested that COR might mimic octadecanoid-derived signaling compounds in higher plants (Feys et al. 1994; Weiler et al. 1994; Boland et al. 1995). Putative plant receptors for JA, OPDA, or COR are still unknown but are the subject of ongoing investigations (Schüler et al. 1999).

During the incompatible interaction (e.g., with tobacco plants), $P$. syringae pv. glycinea elicits the hypersensitive response (HR), a rapid localized necrosis of plant tissue that is associated with programmed cell death and active plant defense at the site of pathogen infection. The ability to elicit the HR on nonhost plants and to be pathogenic on host plants is controlled by HR and pathogenicity ( $h r p$ ) genes, which are universal among phytopathogenic bacteria of the genera Pseudomonas, Erwinia, Xanthomonas, and Ralstonia (Alfano and Collmer 1997). The hrp genes are clustered and many encode components of type III protein secretion systems dedicated to the secretion of virulence proteins into plant cells (He 1998). Nucleotide sequencing of the hrp gene clusters from plant pathogens revealed homologies with components of the yop secretion system of Yersinia spp. and other protein translocation systems of pathogenic bacteria, suggesting the conservation of type III protein secretion pathways in gram-negative pathogens of both plants and animals (He 1998). Numerous studies have dissected this secretion system and mutants were obtained that were impaired at various steps of the respective secretion mechanisms (Lindgren 1997; He 1998). The characteristic phenotype associated with hrp mutants is the inability to cause disease on susceptible host plants, as well as the inability to elicit the HR on resistant cultivars of susceptible plants and on nonhost plants.

To study the influence of temperature and phytotoxin synthesis on virulence of $P$. syringae pv. glycinea during the compatible interaction with soybean plants, we monitored disease outcome by visual estimation of symptom development and by enumeration of bacteria in planta at different temperature and inoculation conditions. Furthermore, we studied the impact of temperature and coronafacoyl compounds during the incompatible interaction of $P$. syringae pv. glycinea with tobacco plants. Here we demonstrate that a CFA-overproducing derivative of $P$. syringae pv. glycinea, PG4180.N9, elicits the HR in a temperature-dependent manner and that the amount of synthesized CFA delayed the outcome of the HR. This effect could be reproduced by the addition of purified CFA to bacterial inocula not producing any coronafacoyl compounds and could be abolished by overproduction of $\mathrm{HrpL}$, the alternative sigma factor involved in transcriptional activation of $h r p$ genes.

\section{RESULTS}

\section{Symptom development and multiplication}

of $P$. syringae pv. glycinea in soybean plants is dependent on the bacterial pre-inoculation temperature.

Symptom development and in planta bacterial multiplication were monitored in soybean plants inoculated with PG4180 and its $\mathrm{COR}^{-}$mutant PG4180.D4 grown at 18 and

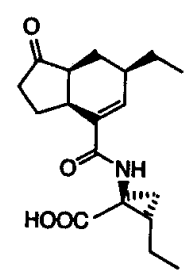

Coronatine

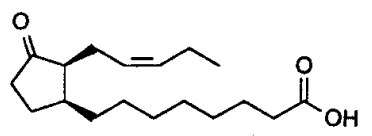

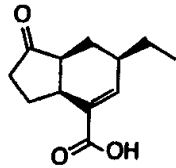

Coronafacic acid

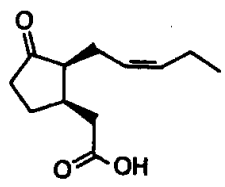

\section{2-oxo-phytodienoic acid Jasmonic acid}

Fig. 1. Structural relatedness of coronatine, coronafacic acid, 12-oxophytodienoic acid, and jasmonic acid. 
$28^{\circ} \mathrm{C}$, respectively. Mutant $\mathrm{PG} 4180 . \mathrm{D} 4$ harbors a transposon insertion in the regulatory $\operatorname{cor} R$ gene that is required for transcriptional activation of the COR biosynthetic genes (Ullrich et al. 1995; Fig. 2) and is completely defective in COR biosynthesis (Fig. 3A). Following inoculation by either spraying or infiltrating the bacterial suspensions to the plant tissue, replica plants were placed in growth chambers set to 18 or $28^{\circ} \mathrm{C}$. When sprayed on soybean plants, PG4180 cells grown at $18^{\circ} \mathrm{C}$ caused severe disease symptoms initially characterized by water-soaked lesions that developed into necrotic spots surrounded by chlorotic halos after 5 to 7 days (Fig. 3B). In contrast, when PG4180 cells grown at $28^{\circ} \mathrm{C}$ were inoculated by spraying, plants exhibited significantly fewer symptoms and were characterized by smaller, water-soaked lesions and reduced necrosis and chlorosis, respectively (Fig. 3C). Soybean plants treated with cell suspensions of the COR ${ }^{-}$mutant PG4180.D4 also developed fewer symptoms that were characterized by less water soaking and smaller, necrotic lesions lacking significant chlorotic halos (data not shown). The pre-inoculation temperature of the PG4180.D4 cultures did not influence this result. Furthermore, the temperature at which the plants were kept post inoculation did not significantly alter the described symptom development. Thus, all subsequent experiments were standardized to a post-inoculation temperature of $28^{\circ} \mathrm{C}$.

To substantiate the results of symptom development, in planta bacterial multiplication was monitored by reisolating bacterial cells from infected plant tissue in a time-dependent manner (Fig. 3D). Results showed that bacterial multiplication was relatively low (100 to 1,000 -fold over 10 days) in plants inoculated with PG4180 grown at $28^{\circ} \mathrm{C}$. In comparison, bacterial growth was higher (10,000-fold over 10 days) in plants inoculated with bacteria derived from $18^{\circ} \mathrm{C}$ cultures. Measurement of bacterial growth in soybean plants exposed to the $\mathrm{COR}^{-}$mutant PG4180.D4 showed low multiplication rates regardless of the pre-inoculation temperature of the bacterial cultures (Fig. 3D). Moreover, the number of viable bacterial cells in those plants appeared to decrease after 6 to 10 days, indicat- ing that the infection process was not successful. These results demonstrated that symptom development was directly correlated with bacterial multiplication in planta and that the disease outcome in the compatible interaction depended on the preinoculation temperature and subsequent phytotoxin production.

To investigate whether this result depended on the inoculation method, soybean plants were also infected by artificial infiltration of PG4180 cells that were grown at either 18 or $28^{\circ} \mathrm{C}$. Typical bacterial blight symptoms were observed at the infiltration sites after 3 to 5 days (data not shown). Interestingly, the pre-inoculation temperature of the bacterial cultures had no effect on symptom development under these inoculation conditions. Additionally, estimation of bacterial growth in planta showed no significant difference between the multiplication rates of PG4180 derived from cultures grown at 18 or $28^{\circ} \mathrm{C}$ (Fig. 3E). Similar results were obtained when PG4180.D4 was infiltrated into soybean plant tissue. In general, multiplication of PG4180.D4 was approximately five- to 10-fold lower than PG4180 and was not influenced by the preinoculation temperature of the bacteria (Fig. 3E). In summary, the results of these experiments indicated that pre-inoculation temperature and phytotoxin synthesis dramatically influenced the bacterial invasion efficiency via natural plant openings but did not significantly affect virulence when the cells were artificially introduced into the plant tissue.

\section{Effect of temperature on the HR.}

Initially, the outcome of the HR was monitored in tobacco plants inoculated with PG4180 grown at either 18 or $28^{\circ} \mathrm{C}$ prior to inoculation. Bacteria were grown in HSC medium to an $\mathrm{OD}_{600}$ of 1.5 to 1.8 (1.7 to $2.2 \times 10^{9} \mathrm{CFU}$ per $\left.\mathrm{ml}\right)$ and then injected into 8-week-old tobacco plants that were subsequently maintained at 18 or $28^{\circ} \mathrm{C}$. After 24,48 , and $72 \mathrm{~h}$ the development of the HR was monitored visually. All inoculated plants exhibited a typical HR at $24 \mathrm{~h}$ post inoculation (hpi) regardless of the bacterial pre-inoculation growth temperature (Fig. 4, top). As shown for the compatible interaction, the

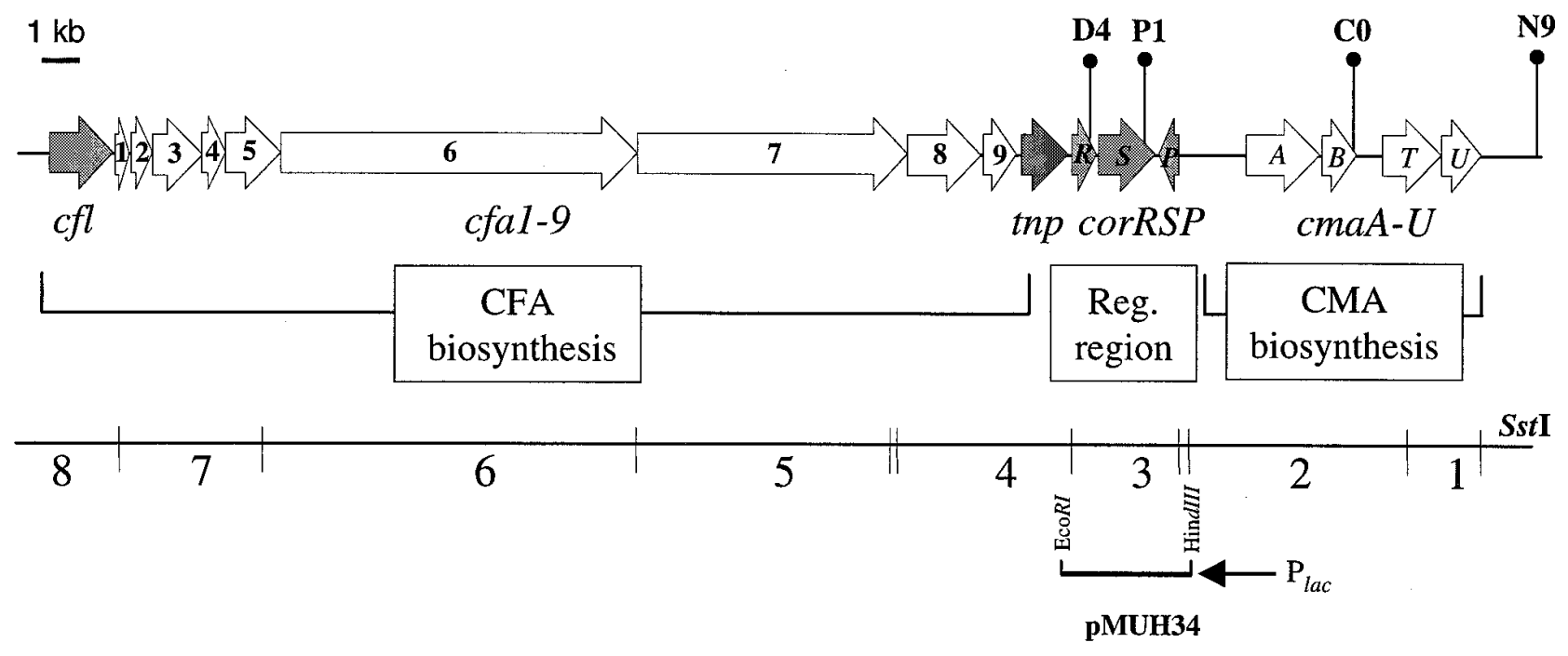

Fig. 2. Genetic and functional organization of the coronatine (COR) biosynthetic gene cluster of Pseudomonas syringae pv. glycinea PG4180. Genes for coronafacic acid (CFA) biosynthesis ( $c f l, c f a l-9)$, for coronamic acid (CMA) biosynthesis ( $c m a A, c m a B$, cmaT, and cmaU), and regulatory genes (corP, corS, and corR) are outlined. Vertical lines with closed circles indicate position of mutational insertions in PG4180.N9 (N9), PG4180.C0 (C0), PG4180.P1 (P1), and PG4180.D4 (D4). Position of the insert DNA of pMUH34 is outlined with respect to the SstI restriction map of the COR gene cluster. tnp is a transposase gene naturally occurring within the gene cluster. 
temperature under which the treated plants were kept did not affect the outcome of the HR. Experiments were repeated with the $\mathrm{COR}^{-}$mutant PG4180.D4 and similar results were obtained. Furthermore, no influence of temperature on the out- come of the HR was observed when the $P$. syringae pv. syringae strain Pss61, a COR ${ }^{-}$strain, and the $\mathrm{COR}^{+}$P. syringae pv. tomato strain DC3000 were used for the inoculation procedure. This demonstrated that neither bacterial growth tem-
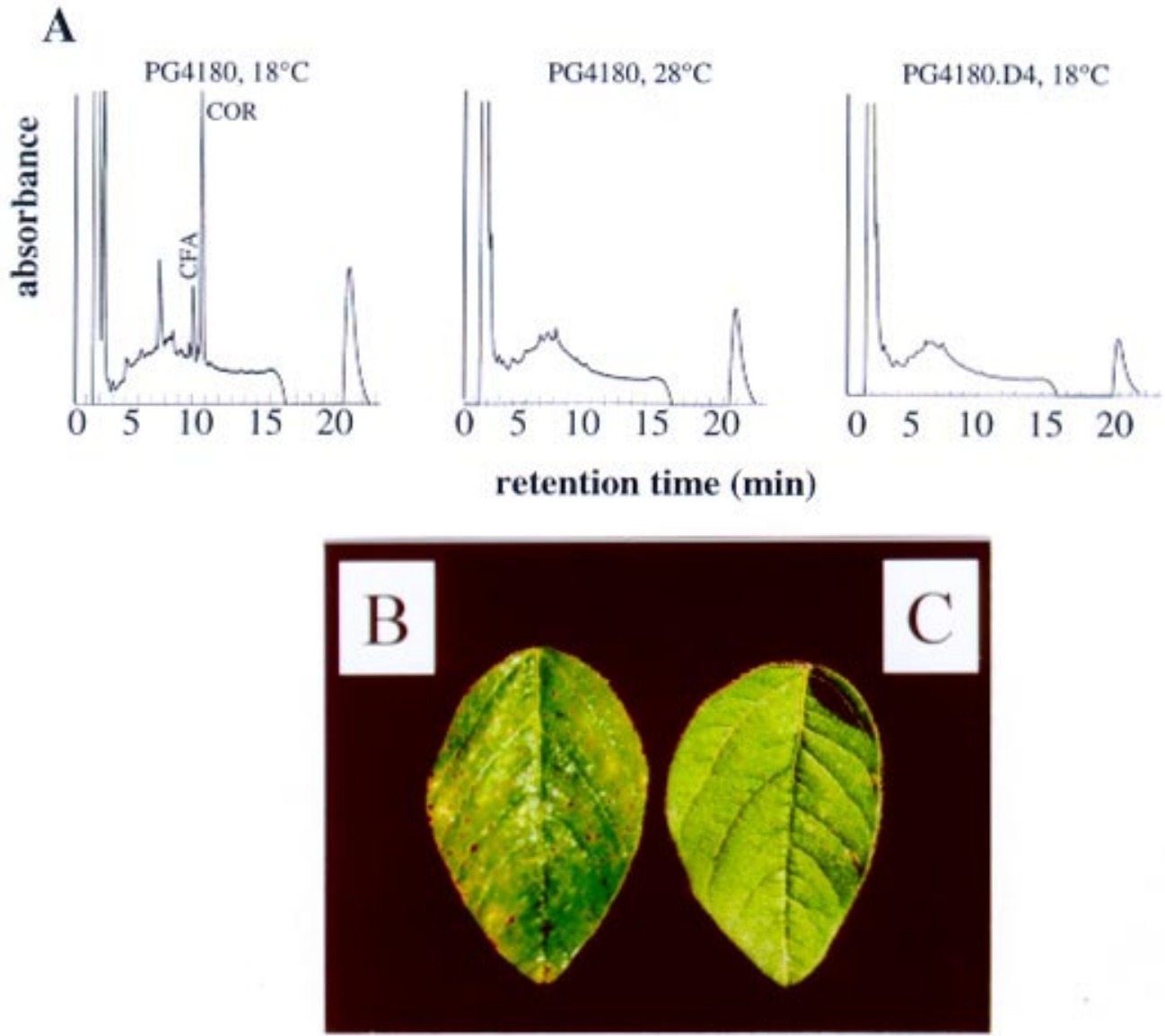

D

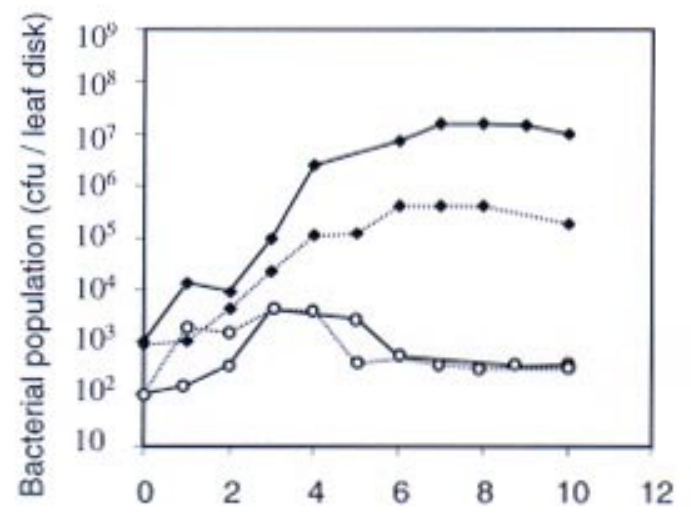

Days after inoculation
E

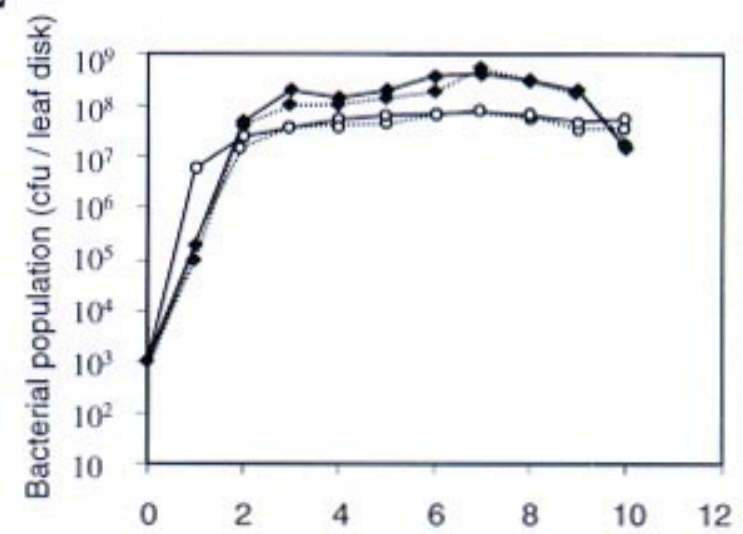

Days after inoculation

Fig. 3. Compatible interaction of Pseudomonas syringae pv. glycinea PG4180 and the COR ${ }^{-}$mutant PG4180.D4 with soybean plants. A, Coronatine (COR) and coronafacic acid (CFA) synthesis in PG 4180 at $18^{\circ} \mathrm{C}$ and lack of synthesis at $28^{\circ} \mathrm{C}$ and in mutant PG4180.D4 at $18^{\circ} \mathrm{C}$ as determined by highperformance liquid chromatography (HPLC) analysis. B, Symptom development at 5 days after spray inoculation with PG4180 pre-incubated at $18^{\circ} \mathrm{C}$. C, Symptoms at 5 days after spray inoculation with PG4180 pre-incubated at $28^{\circ} \mathrm{C}$. D, In planta bacterial multiplication of PG4180 (filled diamonds) and the $\mathrm{COR}^{-}$mutant PG4180.D4 (open circles) after spray inoculation with bacteria derived from either $18^{\circ} \mathrm{C}$ (solid lines) or $28^{\circ} \mathrm{C}$ (dashed lines) cultures. E, In planta bacterial multiplication of PG4180 (filled diamonds) and the COR ${ }^{-}$mutant PG4180.D4 (open circles) after infiltration of bacteria derived from either $18^{\circ} \mathrm{C}$ (solid lines) or $28^{\circ} \mathrm{C}$ (dashed lines) cultures. Results represent data from three experiments, each with two replicates. 
perature nor COR synthesis remarkably influenced the outcome of the HR of tobacco plants.

\section{Temperature-mediated suppression of the HR.}

Next, we tested whether an altered synthesis of COR or CFA could influence the outcome of the HR in tobacco plants. As quantified by HPLC analysis, PG4180 grown to an $\mathrm{OD}_{600}$ of 1.5 to 1.8 produced $2.3 \pm 1 \mathrm{mg}$ of CFA and $7.6 \pm 2 \mathrm{mg}$ of COR per liter at $18^{\circ} \mathrm{C}$. No coronafacoyl compounds could be isolated from PG4180 cultures grown at $28^{\circ} \mathrm{C}$ (Fig. 5). In contrast, the PG4180 derivative PG4180.N9 (Ullrich et al. 1994) overproduced CFA, one of the COR precursors, with $10.1 \pm 3 \mathrm{mg}$ of CFA per liter and $7.3 \pm 1 \mathrm{mg}$ of COR per liter at $18^{\circ} \mathrm{C}$ (CFA and COR synthesis were negligible at $28^{\circ} \mathrm{C}$ ) (Figs. 4 and 5). This strain carries a Tn5 insertion approximately $1.5 \mathrm{~kb}$ downstream of $\mathrm{cmaU}$ in one of the insertion sequence (IS) elements flanking the CMA gene cluster (Fig. 2; Alarcon-Chaidez et al. 1999). The reason for the overproduction of CFA by PG4180.N9 is unknown but the genetic organization of the COR gene cluster in this strain was not altered when investigated by Southern blot hybridization (data not shown). Interestingly, PG4180.N9 caused a remarkably different, temperature-dependent reaction when injected into tobacco plants. Tobacco plants inoculated with PG4180.N9 cells produced a typical $\mathrm{HR}$ at 24 hpi only when the bacterial inoculum was derived from cultures grown at $28^{\circ} \mathrm{C}$ (Fig. 4 , bottom). In $70 \%$ of 50 independent experiments, PG4180.N9 elicited no $\mathrm{HR}$ at $24 \mathrm{hpi}$ when the bacterial inoculum was derived from cultures grown at $18^{\circ} \mathrm{C}$ and produced $11.4 \pm 2 \mathrm{mg}$ of CFA per liter and $7.9 \pm 1 \mathrm{mg}$ COR per liter (Fig. 4). When the treated tobacco plants were re-evaluated at 48 and $72 \mathrm{hpi}$, a HR-like necrosis of the plant tissue could occasionally be observed. These results suggested that PG4180.N9 might produce a factor(s) at $18^{\circ} \mathrm{C}$ that significantly delayed or suppressed the onset of the HR in tobacco plants.

Subsequently, we investigated whether the putative HRdelaying factor(s) were associated with cells or the cell-free supernatant of PG4180.N9. Interestingly, when washed or filtered cells of PG4180.N9 grown at $18^{\circ} \mathrm{C}$ were used as inoculum, the HR was suppressed in only $45 \%$ of 50 independent experiments, suggesting that factors from the original supernatant contributed to the suppression of the HR. As expected,

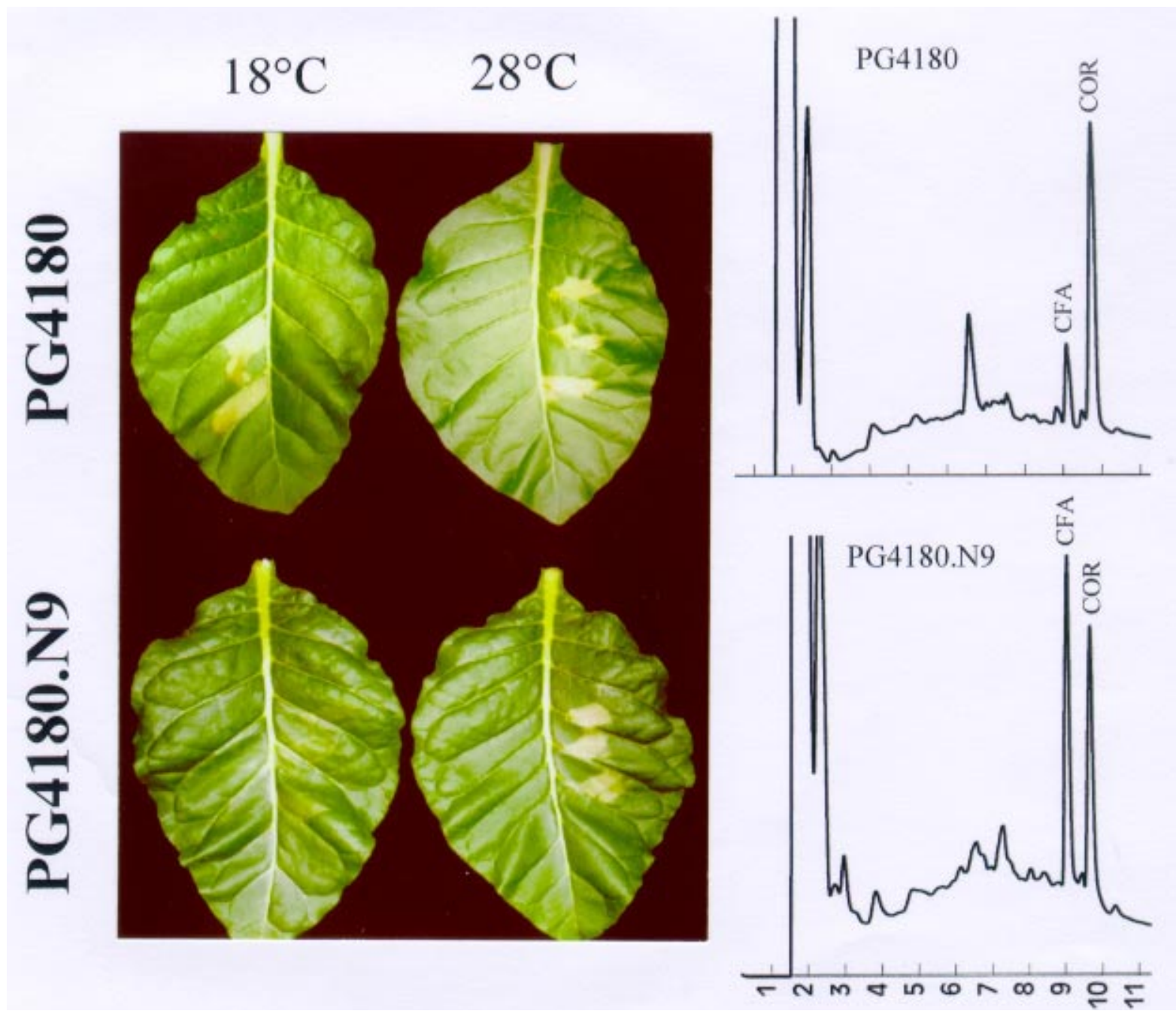

Fig. 4. Hypersensitive response phenotypes on tobacco plants caused by PG4180 and PG4180.N9 pre-incubated at 18 and $28^{\circ} \mathrm{C}$, respectively. Level of coronatine (COR) and coronafacic acid (CFA) production by both strains at $18^{\circ} \mathrm{C}$ is outlined as determined by high-performance liquid chromatography analysis. 
no HR was induced 24 to 72 hpi when tobacco plants were inoculated with cell-free culture supernatants or heat-killed cells grown at $18^{\circ} \mathrm{C}$. This confirmed the established fact that living bacterial cells are essential for the induction of the HR. Our results demonstrated that the HR-suppressing phenotype of PG4180.N9 was only detectable when the cells were grown at $18^{\circ} \mathrm{C}$ and that factors excreted from the cell were required to efficiently suppress the HR.

\section{Comparison of the hrp gene clusters of PG4180 and PG4180.N9.}

To determine whether PG4180.N9 showed abnormalities in the structure of its hrp gene cluster, Southern blot hybridizations were carried out with the insert of cosmid pHIR11 as a nonradioactively labeled probe. Cosmid pHIR11 contains the entire hrp gene cluster of the P. syringae strain Pss61 (Huang et al. 1988). Genomic DNA of PG4180 and PG4180.N9 was cleaved with restriction enzymes EcoRI, EcoRI/HindIII, and EcoRI/BamHI, separated by agarose gel electrophoresis, transferred to a nylon membrane, and hybridized with the probe. The results showed that there was no visible restriction fragment length polymorphism (RFLP) among the two strains (data not shown). Although we cannot rule out point mutations, our results indicate that the hrp gene clusters in these two strains are essentially identical and unlikely cause the temperature-mediated suppression of the HR.

\section{The suppression of the HR caused by PG4180.N9 is growth-medium dependent.}

To determine the effects of medium composition on the phenotype of PG4180.N9, this strain was grown in HSC minimal medium, KB complex medium, and $h r p$-inducing IM medium to an $\mathrm{OD}_{600}$ of 1.5 to 1.8 at 18 and $28^{\circ} \mathrm{C}$. Tobacco
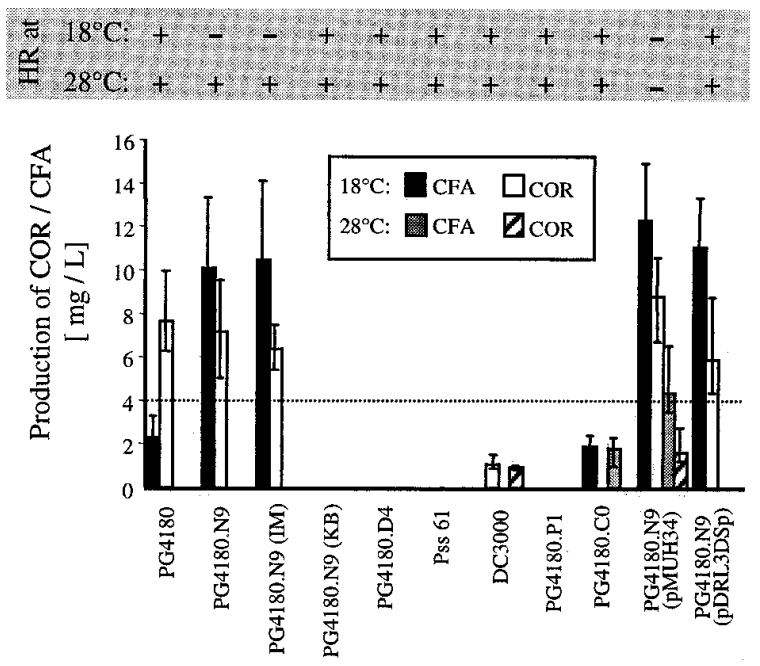

Fig. 5. Quantitative high-performance liquid chromatography (HPLC) analysis showing amounts of coronafacic acid (CFA) and coronatine (COR) (mg/liter) in different Pseudomonas syringae strains as well as evaluation of the hypersensitive response (HR) caused by these bacterial strains on tobacco plants at $24 \mathrm{~h}$ post inoculation. All strains were grown at 18 and $28^{\circ} \mathrm{C}$ in $\mathrm{HSC}$ medium or otherwise indicated media to an $\mathrm{OD}_{600}$ of 1.5 to 1.8 . CFA and COR were extracted from $1.5 \mathrm{ml}$ of cellfree culture supernatants and quantified by HPLC analysis. (+) development of HR; (-) no visible HR. Dashed line = threshold level of CFA synthesis (approx. $4 \mathrm{mg}$ of CFA per liter) required for delay of HR. plants were inoculated with the bacterial culture suspensions and the HR was monitored 24, 48, and 72 hpi. Results for PG4180.N9 grown in HSC medium or in IM medium were identical to those described above. Plants inoculated with PG4180.N9 derived from complex KB medium showed a typical HR after $24 \mathrm{~h}$ regardless of the pre-inoculation temperature. Neither CFA nor COR were produced by PG4180.N9 grown in KB medium (Fig. 5). In IM medium, this strain produced CFA and $\mathrm{COR}$ at $18^{\circ} \mathrm{C}$ in amounts similar to those synthesized in HSC medium $(10.4 \pm 3.7 \mathrm{mg}$ of CFA per liter and $6.35 \pm 1.1 \mathrm{mg}$ of COR per liter) but did not produce any coronafacoyl compounds at $28^{\circ} \mathrm{C}$ (Fig. 5). These results indicated that the HR phenotype of PG4180.N9 was nutrient dependent and correlated with the overproduction of CFA in minimal media.

\section{Influence of thermoresponsive CFA production by various PG4180 derivatives on elicitation of the HR.}

Strains PG4180 and PG4180.N9 differed remarkably with respect to CFA production (Fig. 5) and their respective HR phenotypes (Fig. 4), but not with respect to COR synthesis. This prompted us to investigate whether the amount of CFA had a role in the outcome of the HR. Initially, another mutant, PG4180.C0, that produces CFA but no COR (Bender et al. 1993) was considered. This mutant consistently produced only about one-fifth of the CFA amount synthesized by PG4180.N9 (Fig. 5). When tested in HR experiments, no effect of preinoculation temperature was observed for PG4180.C0, possibly because the amount of CFA produced $(1.88 \pm 0.5 \mathrm{mg} / \mathrm{liter}$ at $18^{\circ} \mathrm{C}$ and $1.77 \pm 0.8 \mathrm{mg} /$ liter at $28^{\circ} \mathrm{C}$ ) was not sufficient to suppress the $\mathrm{HR}$. We then utilized the $\mathrm{CFA}^{-} \mathrm{COR}^{-}$mutant PG4180.P1, which is a PG4180.N9 derivative harboring a $\mathrm{Gm}^{\mathrm{r}}$ cassette in $\operatorname{cor} S$, the gene encoding the histidine protein kinase CorS (Ullrich et al. 1995; Fig. 2). Cell suspensions of PG4180.P1 elicited a typical HR at 24 hpi when derived from either 18 or $28^{\circ} \mathrm{C}$ cultures. Since PG4180.P1 is a derivative of PG4180.N9, this result suggested that the temperatureresponsive HR phenotype of PG4180.N9 was not linked to any additional chromosomal alteration in this strain.

Simultaneous lack of CFA production and HR suppressiveness by PG4180.P1 furthermore strengthened our hypothesis that the amount of CFA might be critical for suppression of the HR. To test this hypothesis, plasmid pMUH34 (Ullrich et al. 1995), which harbors the COR regulatory genes corR, corS, and $\operatorname{corP}$ (Fig. 2), was introduced into PG4180.N9. In addition to the high level of produced COR $(8.8 \pm 2 \mathrm{mg} / \mathrm{liter})$ and CFA (12.3 $\pm 3 \mathrm{mg} / \mathrm{liter})$ at $18^{\circ} \mathrm{C}$, PG4180.N9 (pMUH34) synthesized considerable amounts of CFA $(4.5 \pm 2 \mathrm{mg} / \mathrm{liter})$ and COR ( $1.6 \pm 1 \mathrm{mg} /$ liter) at $28^{\circ} \mathrm{C}$ (Fig. 5), possibly because of copy number effects of the regulatory genes in trans. The transconjugants were grown at 18 and $28^{\circ} \mathrm{C}$ and subsequently tested in HR assays. Interestingly, PG4180.N9 (pMUH34) grown at 18 or $28^{\circ} \mathrm{C}$ did not induce a HR in tobacco plants at 24 hpi (Fig. 5). When re-evaluated after 48 and 72 h, a HRlike necrosis occasionally developed at the sites of infiltration. These results indicated that bacterial strains that produced no or low amounts of CFA caused a typical HR at 24 hpi. Furthermore, our results suggested that cells that produced CFA above the threshold value of approximately $4.0 \mathrm{mg} / \mathrm{liter}$ (19 $\mu \mathrm{M}$ concentration of CFA) caused a significant delay or a suppression of the HR. 


\section{Addition of purified CFA alters the outcome of the HR.}

To further substantiate the potential role of CFA in HR suppression, feeding experiments with purified coronafacoyl compounds were carried out. Cultures of PG4180.N9 were grown at $28^{\circ} \mathrm{C}$ to an $\mathrm{OD}_{600}$ of 1.5 to 1.8 and injected into tobacco leaf tissue. Subsequently, purified CFA (100 $\mu \mathrm{M})$, COR $(100 \mu \mathrm{M})$, or sterile HSC medium were individually infiltrated at 0,3 , or 6 hpi or successively at 3 and 6 hpi into the same area of the leaf, which was pre-inoculated with PG4180.N9 grown at $28^{\circ} \mathrm{C}$ (Fig. 6). The infiltration of CFA, COR, and HSC medium at 0,3 , or 6 hpi had no impact on the development of HR (Fig. 6); all leaf areas inoculated with bacteria exhibited a clear HR at 24 hpi. In contrast, the HR in response to cells grown at $28^{\circ} \mathrm{C}$ was abolished in $65 \%$ of 25 independent experiments when CFA $(100 \mu \mathrm{M})$ was added successively 3 and 6 hpi (Fig. 6). When COR $(100 \mu \mathrm{M})$ was infiltrated at 3 and 6 hpi a delay in the HR occurred in only $18 \%$ out of 25 independent experiments. Sterile HSC medium had no impact on the outcome of the HR when injected after 3 and 6 hpi (Fig. 6). To confirm these results, various concentrations of CFA $(0,25,50,100$, and $200 \mu \mathrm{M})$ were added at 3.5 and 6.5 hpi to tobacco leafs that were pre-infiltrated with washed PG4180.N9 cells grown at $28^{\circ} \mathrm{C}$ (Fig. 7). Although addition of $200 \mu \mathrm{M}$ CFA to the inoculated leaf areas often caused an atypical, grayish, HR-unlike necrosis of the tissue (data were therefore omitted from Figure 7), the lower CFA treatments showed a rather clear concentration-dependent suppression of the HR in at least 15 independent experiments. At this point, it remains obscure why addition of $50 \mu \mathrm{M}$ CFA had a less suppressive effect on the outcome of the HR than addition of 25 $\mu \mathrm{M}$ CFA. In summary, our results clearly showed that purified CFA had the potential to suppress the HR in tobacco plants. Why COR had a negative impact on the outcome of the HR in some experiments remains unclear at the moment.

Since CFA is a structural analogue of JA, we investigated JA for a similar effect on the HR in tobacco tissue. Like CFA, JA $(100 \mu \mathrm{M})$ was infiltrated 3 and 6 hpi into tobacco leaves pre-inoculated with $\mathrm{PG} 4180 . \mathrm{N} 9$ cells grown at $28^{\circ} \mathrm{C}$. Evaluation of the HR at 24 hpi demonstrated that JA had no inhibitory effect on the outcome of the HR (Fig. 6). Based on these results it could be speculated that exogenously added CFA but not the addition of JA might influence the signal transduction pathway leading to the HR.

\section{Overexpression of $h r p L$ results in the elicitation of the HR at low temperature.}

To fully restore the ability of PG4180.N9 to cause an HR on tobacco plants when pre-incubated in minimal medium at $18^{\circ} \mathrm{C}$, plasmid pDRL3DSp was conjugated into PG4180.N9. This plasmid carries a transcriptional fusion of $h r p L$ to the inducible $\mathrm{P}_{\text {lac }}$ promoter (S. W. Hutcheson, personal communications). The gene product of $h r p L$ represents an alternative sigma factor governing the expression of the hrp gene cluster and thus functioning as a key regulator for $\mathrm{HR}$ induction (He 1998). PG4180.N9 (pDRL3DSp) produced amounts of CFA $(11.04 \pm 2.3 \mathrm{mg} / \mathrm{liter})$ and COR $(5.85 \pm 2.9 \mathrm{mg} / \mathrm{liter})$ similar to that of the parental strain (Fig. 5). Upon induction with $5 \mathrm{mM}$ IPTG at an $\mathrm{OD}_{600}$ of 0.5 , bacterial cultures were injected into tobacco leaves after they reached an $\mathrm{OD}_{600}$ of 1.5 to 1.8 and the resulting HR was evaluated at 24,48 , and 72 hpi. All treated plants developed a typical HR regardless of the bacte- rial pre-inoculation temperature, indicating that $h r p L$ overexpression abolished the thermosensitive delay of the HR and the suppressive effects of CFA.

\section{DISCUSSION}

In the present study, we investigated the impact of temperature and synthesis of coronafacoyl compounds on $P$. syringae during compatible and incompatible interactions with soybean and tobacco plants, respectively. Special emphasis was put on the bacterial component because changes in the temperature at which the plants were maintained did not significantly influence the outcome of the interaction. Plants like soybeans or tobacco obviously do not depend on small temperature changes when responding to this pathogen.

$P$. syringae PG4180 preferentially produces the phytotoxin $\mathrm{COR}$ and its precursor, CFA, at $18^{\circ} \mathrm{C}$ whereas no detectable $\mathrm{COR}$ or CFA is produced at $28^{\circ} \mathrm{C}$. Several previous reports demonstrated that $\mathrm{COR}^{-}$mutants of $P$. syringae caused smaller lesions and exhibited lower levels of bacterial multiplication in plants than $\mathrm{COR}^{+}$strains (Bender et al. 1987; Mittal and Davis 1995; Tamura et al. 1998). Our results indicate that the synthesis of coronafacoyl compounds by PG4180 is also important for the initial steps in the compatible plantmicrobe interaction. In plants inoculated by spraying, a smaller number of bacteria enter the host via stomata, other natural openings, or wounds than in plants inoculated by infiltration. These low levels of inoculum resemble to some extent naturally occurring infections (Beattie and Lindow 1999). Consequently, our data suggest that COR synthesis at low temperature was advantageous for the bacterial multiplication in planta. In infiltrated soybean plants, the effects of preinoculation temperature and COR synthesis were masked by the artificial and massive introduction of bacteria into the mesophyll tissue. Interestingly, the $\mathrm{COR}^{-}$mutant PG4180.D4 did not produce significant disease symptoms, regardless of the growth temperature, when spray inoculated onto soybean plants but reached considerable cell densities when artificially introduced into plants. This result indicated that COR synthesis might be important in the early steps of the infection. Similar results were reported by Mittal and Davis (1995) for the $P$. syringae pv. tomato-A. thaliana interaction.

In the incompatible interaction with tobacco plants, PG4180 elicited the HR regardless of the pre-inoculation growth temperature. This result clearly demonstrated that COR did not influence the outcome of the HR during the incompatible interaction. However, the CFA-overproducing derivative, PG4180.N9, elicited the HR 24 hpi when pre-incubated at $28^{\circ} \mathrm{C}$ but barely when grown at $18^{\circ} \mathrm{C}$, a temperature at which this strain synthesizes large amounts of CFA. Our results also indicate that the delay of the HR depended on factors derived from the bacterial supernatant. To our knowledge, PG4180.N9 is the only bacterial strain able to secrete large amounts of $\mathrm{CFA}$, and suppression of the HR required at least $4 \mathrm{mg}$ of CFA per liter of culture medium.

Since the thermosensitive delay of the HR was tightly linked to strain PG4180.N9, additional chromosomal alterations within this strain eventually related to the hrp gene cluster had to be ruled out. According to RFLP analysis, it was shown that the hrp gene clusters of PG4180.N9 and its parental strain were very similar if not identical. Furthermore, 
overproduction of HrpL in PG4180.N9 abolished the delay of the HR, suggesting that this strain is fully capable of eliciting the HR. From those results, taken together, it can be concluded that the interesting HR delay phenotype of this strain may not be related to defects in hrp genes or their regulation.

This is the first report demonstrating that the HR can be inhibited by the bacterial compound CFA, a molecular mimic of plant-borne JA. Previously, it was demonstrated that the HR of leaf tissue toward bacteria could be prevented by treatments with several compounds such as calcium, strontium, and uranium salts (Cook and Stall 1971), cytokinins (Novacky 1972), glycoproteins of the bacterial cell wall (Wacek and Sequeira 1973), the phytotoxin phaseolotoxin (Rose and Rudolph 1976), or subcellular bacterial components, such as lipopolysaccharides or protein-lipopolysaccharide complexes (Graham et al. 1977; Minardi 1995; Newman et al. 1997) as well as by extracellular polysaccharides (Mazzucchi and Rudolph, 1984). Furthermore, Robinette and Matthysse (1990) described that the HR can be delayed by injection of Agrobacterium tumefaciens prior to injection of $P$. syringae pv. phaseolicola.

When we added bacterial CFA prior to the injection of PG4180.N9 into tobacco leaves, the HR was visible at $24 \mathrm{hpi}$, resulting in complete tissue collapse. Similar results were obtained when CFA was added to PG4180.N9 cultures grown at $28^{\circ} \mathrm{C}$ or to infiltrated leaf areas alternatively at 0,3 , or $6 \mathrm{hpi}$. In contrast, the HR was blocked when bacterial CFA was added successively at 3 and 6 hpi to the same leaf tissue that was inoculated with PG4180.N9 grown at $28^{\circ} \mathrm{C}$. With different concentrations of added CFA, these data could be confirmed. A nearly linear correlation between the amount of added CFA and the suppression of the HR could be observed. These results indicated that the timing and quantity of CFA build-up within the infiltrated leaf area were essential for CFA's mode of action as an HR-delaying compound and pos-
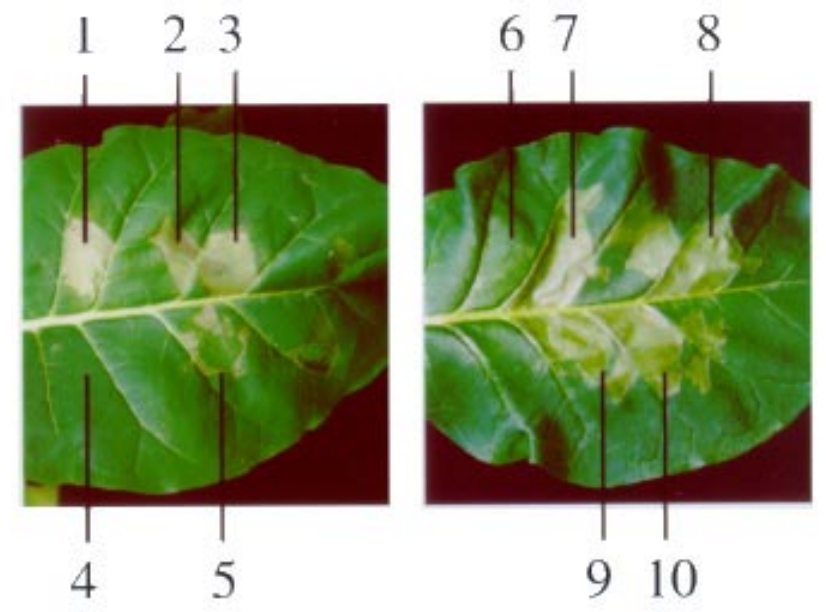

Fig. 6. Addition of coronafacic acid (CFA) to leaf areas initially infiltrated with PG4180.N9 cells derived from cultures pre-incubated at 18 or $28^{\circ} \mathrm{C}$. Applied samples: 1, PG4180.N9 $28^{\circ} \mathrm{C}$; 2, PG4180.N9 $28^{\circ} \mathrm{C}+$ $100 \mu \mathrm{M} \mathrm{CFA}$ at $3 \mathrm{~h}$ post inoculation (hpi) (entire area); 3, PG4180.N9 $28^{\circ} \mathrm{C}+100 \mu \mathrm{M} \mathrm{CFA}$ at $6 \mathrm{hpi}$ (entire area); 4, PG4180.N9 $18^{\circ} \mathrm{C} ; 5$, PG4180.N9 $28^{\circ} \mathrm{C}+100 \mu \mathrm{M}$ CFA at 3 and 6 hpi (entire area); 6, PG4180.N9 $18^{\circ} \mathrm{C}$; 7, PG4180.N9 $28^{\circ} \mathrm{C}$; 8, PG4180.N9 $28^{\circ} \mathrm{C}+\mathrm{HSC}$ medium at 3 and 6 hpi (entire area); 9, PG4180.N9 $28^{\circ} \mathrm{C}+100 \mu \mathrm{M}$ coronatine (COR) at 3 and 6 hpi (entire area); 10, PG4180.N9 $28^{\circ} \mathrm{C}+$ $100 \mu \mathrm{M}$ jasmonic acid (JA) at 3 and 6 hpi (entire area). sible molecular mimic of JA. Kenton et al. (1999) recently demonstrated that tobacco leaves infected with $P$. syringae pv. phaseolicola and undergoing the HR showed a significant JA accumulation within the developing lesions between 3 and 9 hpi. Likewise, Veronesi et al. (1996) and Rickauer et al. (1997) reported that the production of JA increased within the first hours after elicitor treatment. Based on this, we conclude that the presence of CFA at 3 and 6 hpi within the treated leaf tissue is essential to suppress the proper development of a HR. However, in almost half of our experiments with supernatantfree PG4180.N9 cells grown at $18^{\circ} \mathrm{C}$ we could also observe a delay in HR development. We speculate that this result may be attributed to the amount of CFA synthesized by PG4180.N9 de-novo inside the plant tissue.

In summary, our results showed that synthesis of coronafacoyl compounds by $P$. syringae pv. glycinea is important for the initial steps in both compatible and incompatible plantmicrobe interactions. COR is required for the initial establishment of bacterial populations at the infection site whereas its precursor, CFA, plays an important role in preventing pathogen recognition. Further studies of this fascinating interplay between plant defense and bacterial secondary metabolism are currently underway in our laboratory.

\section{MATERIALS AND METHODS}

\section{Bacterial strains and culture conditions.}

The bacterial strains and plasmids used in this study are listed in Table 1. P. syringae was routinely maintained on King's medium B (KB; King et al. 1954) or on mannitolglutamate medium (MG; Keane et al. 1970) at $28^{\circ} \mathrm{C}$. For liquid cultures at 18 or $28^{\circ} \mathrm{C}$, bacteria were incubated in $\mathrm{KB}$ medium, HSC medium (Hoitink-Sinden minimal medium optimized for COR production; Palmer and Bender 1993) or in hrp-inducing minimal medium (IM; Huynh et al. 1989) as described previously (Budde et al. 1998). The Escherichia coli strain DH5 $\alpha$ was used in cloning studies and was grown in Luria-Bertani (LB) broth at $37^{\circ} \mathrm{C}$. Bacterial growth was monitored by measuring the optical density at $600 \mathrm{~nm}$

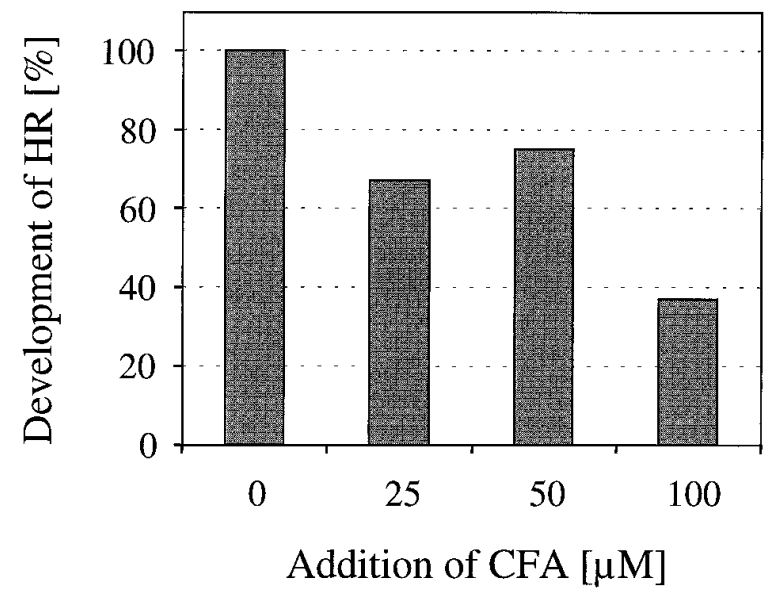

Fig. 7. Development of hypersensitive response (HR) following addition of various amounts of purified coronafacic acid (CFA) to tobacco leaves pre-infiltrated with washed PG4180.N9 cells grown at $28^{\circ} \mathrm{C}$. Bars $=$ outcome of HR (\%) when CFA was added at 3.5 and $6.5 \mathrm{~h}$ post inoculation for at least 15 independent experiments. 
$\left(\mathrm{OD}_{600}\right)$. The following antibiotics were added to media when needed: kanamycin, $25 \mu \mathrm{g} / \mathrm{ml}$; spectinomycin, $25 \mu \mathrm{g} / \mathrm{ml}$; streptomycin, $25 \mu \mathrm{g} / \mathrm{ml}$; tetracycline, $25 \mu \mathrm{g} / \mathrm{ml}$.

\section{Standard genetic procedures.}

Isolation of genomic DNA from $P$. syringae, agarose gel electrophoresis, restriction enzyme digestions, purification of DNA fragments from agarose gels, triparental matings, and electroporations were performed by standard techniques (Sambrook et al. 1989). Preparations of large-scale plasmid DNA were carried out with the Plasmid Midi kit (Qiagen, Hilden, Germany). Southern hybridizations were carried out according to a nonradioactive DNA labeling and detection kit (Boehringer-Mannheim, Mannheim, Germany) following the manufacturer's recommendation.

\section{Isolation and quantitation of coronafacoyl compounds.}

Organic acids were extracted from cell-free bacterial supernatants $(1.5 \mathrm{ml})$, analyzed and quantified for the presence of CFA and COR by an established high pressure liquid chromatography (HPLC) method (Palmer and Bender 1993). For feeding experiments, large amounts of CFA and COR (approximately 30 to $60 \mathrm{mg} / \mathrm{liter}$ ) were isolated by extraction with ethyl acetate from 5-day-old cultures of $P$. syringae pv. glycinea grown at $18^{\circ} \mathrm{C}$ in HSC medium. Both compounds were subsequently purified by thin-layer-chromatography (TLC) as described by Mitchell (1984). TLC-purified coronafacoyl compounds were dissolved in water, quantified by HPLC analysis, and subsequently added to cell suspensions, cell-free media, or leaf tissue as described below.

\section{Plant material, inoculation procedures, and HR assays.}

Soybean plants (Glycine max (L.) Merr. 'Maple Arrow') and tobacco plants (Nicotiana tabacum cv. Petit Havana SR1)

Table 1. Bacterial strains and plasmids

\begin{tabular}{|c|c|c|}
\hline Strain or plasmid & Relevant characteristics & Reference \\
\hline \multicolumn{2}{|l|}{ Escherichia coli $\mathrm{DH} 5 \alpha$} & Sambrook et al. 1989 \\
\hline \multicolumn{3}{|c|}{ Pseudomonas syringae pv. glycinea } \\
\hline PG4180 wild type & $\mathrm{COR}^{+} \mathrm{CMA}^{+} \mathrm{CFA}^{+}$ & Bender et al. 1993 \\
\hline PG4180.N9 & $\mathrm{COR}^{+} \mathrm{CMA}^{+} \mathrm{CFA}^{+} \mathrm{Km}^{\mathrm{r}}$ & Ullrich et al. 1994 \\
\hline PG4180.P1 & $\begin{array}{l}\mathrm{COR}^{-} \mathrm{CMA}^{-} \mathrm{CFA}^{-} \mathrm{Km}^{\mathrm{r}} \mathrm{Gm}^{\mathrm{r}} \\
\quad \text { cor } S \text { mutant }\end{array}$ & Ullrich et al. 1995 \\
\hline PG4180.C0 & $\mathrm{COR}^{-} \mathrm{CMA}^{-} \mathrm{CFA}^{+} \mathrm{Km}^{\mathrm{r}}$ & Bender et al. 1993 \\
\hline PG4180.D4 & $\mathrm{COR}^{-} \mathrm{CMA}^{-} \mathrm{CFA}^{-} \mathrm{Km}^{\mathrm{r}}$ & Bender et al. 1993 \\
\hline \multicolumn{3}{|c|}{ P. syringae pv. syringae } \\
\hline Pss61 & $\mathrm{COR}^{-} \mathrm{CMA}^{-} \mathrm{CFA}^{-}$ & A. Collmer \\
\hline \multicolumn{3}{|l|}{ P. syringae pv. tomato } \\
\hline DC3000 & $\mathrm{COR}^{+} \mathrm{CMA}^{+} \mathrm{CFA}^{+}$ & D. A. Cuppels \\
\hline \multicolumn{3}{|l|}{ Plasmids } \\
\hline pMUH34 & $\begin{array}{l}\mathrm{Tc}^{\mathrm{r}} \text {; contains a 3.4-kb HindIII/ } \\
\text { EcoRI insert derived from } \\
\text { p4180A in pRK415; required } \\
\text { for complementation of COR } \\
\text { CMA }^{-} \mathrm{CFA}^{-} \text {PG4180 mutants }\end{array}$ & Ullrich et al. 1995 \\
\hline pHIR11 & $\begin{array}{l}\mathrm{Tc}^{\mathrm{r}} ; 25-\mathrm{kb} \text { cosmid containing } \\
\text { the } P \text {. syringae pv. syringae } \\
61 \text { hrp gene cluster }\end{array}$ & Huang et al. 1988 \\
\hline pDRL3D & $\begin{array}{l}\mathrm{Km}^{\mathrm{r}} ; 8.71-\mathrm{kb} \text { plasmid contain- } \\
\text { ing } h r p L \text { under the control of } \\
\text { the } \mathrm{P}_{\text {lac }} \text { promoter }\end{array}$ & S.W. Hutcheson \\
\hline pDRL3DSp & $\begin{array}{l}\mathrm{Km}^{\mathrm{r}} \mathrm{Sm}^{\mathrm{r}} \mathrm{Sp} \mathrm{p}^{\mathrm{r}} ; 10.8-\mathrm{kb} \text { plasmid } \\
\text { containing } h r p L \text { under the } \\
\text { control of the } \mathrm{P}_{\text {lac }} \text { promoter }\end{array}$ & This study \\
\hline
\end{tabular}

were grown in a greenhouse at 20 to $25^{\circ} \mathrm{C}, 60 \%$ humidity, with a 12 -h photoperiod (15,000 lux). Four-week-old soybean plants were inoculated by two different methods. Plants were either sprayed with bacterial cultures grown at 18 and $28^{\circ} \mathrm{C}$ to an $\mathrm{OD}_{600}=1.0$ (approximately $1 \times 10^{9} \mathrm{CFU}$ per $\mathrm{ml}$ ) or the bacteria were infiltrated into leaves by means of a needleless syringe at an $\mathrm{OD}_{600}=0.001\left(1 \times 10^{6} \mathrm{CFU}\right.$ per ml $)$. Following inoculation, soybean plants were transferred to a growth chamber (Controlled Environments, Pembina, ND) at 18 or $28^{\circ} \mathrm{C}, 80 \%$ humidity, and a 12 -h photoperiod $(15,000$ lux; cold white fluorescent light). For determination of the in planta growth of $P$. syringae, three leaf disks $\left(0.5 \mathrm{~cm}^{2}\right)$ from different plants were removed, surface sterilized with $70 \%$ ethanol, pooled, and homogenized in sterile $0.9 \% \mathrm{NaCl}$. Serial dilutions were subsequently plated onto $\mathrm{KB}$ agar plates for determination of the number of CFU per milliliter. To acclimatize tobacco plants for bacterial inoculations, 8-week-old plants were placed in growth chambers set to 18 or $28^{\circ} \mathrm{C} 24 \mathrm{~h}$ before inoculation. Bacterial cultures grown at either 18 or $28^{\circ} \mathrm{C}$ to an $\mathrm{OD}_{600}$ of 1.5 to $1.8\left(1.7\right.$ to $\left.2.2 \times 10^{9} \mathrm{CFU} / \mathrm{ml}\right)$ were infiltrated into the third and fourth tobacco leaf with a syringe. For generation of washed cells and cell-free supernatants, culture suspensions of an $\mathrm{OD}_{600}$ of 1.5 to 1.8 were centrifuged at $5,000 \times g$ for $10 \mathrm{~min}$ and filtered through membranes with $0.2-\mu \mathrm{m}$-diameter pores. The sterile bacterial supernatants were then directly injected into the leaf tissue. To obtain supernatant-free cells without centrifugation, cell suspensions were directly filtered through membranes $(0.2-\mu \mathrm{m}$-diameter pores) and cells were subsequently washed from the surface of the membranes. Bacterial cells were resuspended in fresh HSC medium and their density was adjusted to an $\mathrm{OD}_{600}$ of 1.5 to 1.8. Subsequently, the cells were infiltrated into tobacco plant tissue. Purified coronafacoyl compounds $(100 \mu \mathrm{M}$ COR and $25,50,100$, or $200 \mu \mathrm{M}$ CFA suspended in HSC medium) were added to the bacterial inoculum or into pre-infiltrated or untreated tobacco leaf tissue. As negative controls, tobacco plants were infiltrated with sterile, distilled water, HSC, KB, or IM medium. Infiltrated areas were monitored for development of the HR in form of necrosis covering the entire infiltrated leaf area at 24,48 , and $72 \mathrm{hpi}$.

\section{hrpL overexpression with the $\mathbf{P}_{\text {lac }}$ promoter.}

Plasmid pDRL3D contains a transcriptional fusion of the $P$. syringae Pss61 hrpL gene to the $\mathrm{P}_{l a c}$ promoter (S. W. Hutcheson, personal communication). To guarantee proper selection, a spectinomycin/streptomycin resistance gene cassette was inserted into the EcoRI recognition site of plasmid pDRL3D to yield pDRL3DSp. Plasmid pDRL3DSp was mobilized into P. syringae pv. glycinea PG4180.N9 and transconjugants were selected on MG medium supplemented with kanamycin and spectinomycin. The presence of pDRL3DSp in PG4180.N9 was confirmed by agarose gel electrophoresis of plasmid DNA preparations. To express the $h r p L$ gene, PG4180.N9 containing pDRL3DSp was grown at 18 and $28^{\circ} \mathrm{C}$ to an $\mathrm{OD}_{600}$ of 0.5 , induced with $5 \mathrm{mM}$ IPTG, and subsequently incubated until the cultures reached an $\mathrm{OD}_{600}$ of 1.5 to 1.8. Aliquots of cell suspensions $(1.5 \mathrm{ml})$ were taken prior to and after induction, pelleted by centrifugation, and resuspended in protein extraction buffer (50 mM Tris, $200 \mathrm{mM} \mathrm{NaCl}, 1 \mathrm{mM}$ EDTA, 5 $\mathrm{mM}$ dithiothreitol, $\mathrm{pH}$ 7.4). Samples were then sonicated and centrifuged at $14,000 \times g$ for $20 \mathrm{~min}$ at $4^{\circ} \mathrm{C}$. Pellets were dis- 
carded, and the supernatants were subsequently analyzed by sodium dodecyl sulfate-polyacrylamide gel electrophoresis (SDS-PAGE) for production of HrpL.

\section{ACKNOWLEDGMENTS}

This work was supported by grants of the Max-Planck-Gesellschaft and the Deutsche Forschungsgemeinschaft. We wish to thank Bianca Pohlack for excellent technical assistance. We are grateful to Carol L. Bender, Steve W. Hutcheson, and Alan Collmer for stimulating discussions and for providing bacterial strains and plasmids.

\section{LITERATURE CITED}

Alarcon-Chaidez, F. J., Penaloza-Vazquez, A., Ullrich, M., and Bender, C. L. 1999. Characterization of plasmids encoding the phytotoxin coronatine in Pseudomonas syringae. Plasmid 42:210-220.

Alfano, J. R., and Collmer, A. 1997. The type III (Hrp) secretion pathway of plant pathogenic bacteria: Trafficking harpins, Avr proteins, and death. J. Bacteriol. 179:5655-5662.

Beattie, G. A., and Lindow, S. E. 1999. Bacterial colonization of leaves: A spectrum of strategies. Phytopathology 89:353-359.

Bender, C., Liyanage, H., Palmer, D., Ullrich, M., Young, S., and Mitchell, R. 1993. Characterization of the genes controlling biosynthesis of the polyketide phytotoxin coronatine including conjugation between coronafacic and coronamic acid. Gene 133:31-38.

Bender, C., Stone, H. E., Sims, J. J., and Cooksey, D. A. 1987. Reduced pathogen fitness of Pseudomonas syringae pv. tomato Tn5 mutants defective in coronatine production. Physiol. Mol. Plant Pathol. 30: 273-283.

Blechert, S., Bockelmann, C., Fusslein, M., Von Schrader, T., Stelmach, B., Niesel, U., and Weiler, E. W. 1999. Structure-activity analyses reveal the existence of two separate groups of active octadecanoids in elicitation of the tendril-coiling response of Bryonia dioica Jacq. Planta 207:470-479.

Boland, W., Hopke, J., Donath, J., Nüske, J., and Bublitz, F. 1995. Jasmonic acid and coronatine induce odor production in plants. Angew. Chem. Int. Ed. Engl. 34:1600-1602.

Budde, I. P., Rohde, B. H., Bender, C. L., and Ullrich, M. S. 1998. Growth phase and temperature influence promoter activity, transcript abundance, and protein stability during biosynthesis of the Pseudomonas syringae phytotoxin coronatine. J. Bacteriol. 180:1360-1367.

Cook, A. A., and Stall, R. E. 1971. Calcium suppression of electrolyte loss from pepper leaves inoculated with Xanthomonas vesicatoria. Phytopathology 61:484-487.

Dittrich, H., Kutchan, T. M., and Zenk, M. H. 1992. The jasmonate precursor, 12-oxo-phytodienoic acid, induces phytoalexin synthesis in Petroselinum crispum cell cultures. FEBS Lett. 309:33-36.

Dunleavy, J. M. 1988. Bacterial, fungal, and viral diseases affecting soybean leaves. Pages 40-46 in: Soybean Diseases of the North Central Region. T. D. Wyllie and D. H. Scott, eds. American Phytopathological Society, St. Paul, MN.

Farmer, E. E., and Ryan, C. A. 1990. Interplant communication: Airborne methyl jasmonate induces synthesis of proteinase in plant leaves. Proc. Natl. Acad. Sci. USA 87:7713-7716.

Ferguson, I. B., and Mitchell, R. N. 1985. Stimulation of ethylene production in bean leaf discs by the pseudomonad phytotoxin coronatine. Plant Physiol. 77:969-973.

Feys, B. J., Benedetti, C. E., Penfold, C. N., and Turner, J. G. 1994. Arabidopsis mutants selected for resistance to the phytotoxin coronatine are male sterile, insensitive to methyl jasmonate, and resistant to a bacterial pathogen. Plant Cell 6:751-759.

Graham, T. L., Sequeira, L., and Huang, S. R. 1977. Bacterial lipopolysaccharides as inducer of disease resistance in tobacco. Appl. Environ. Microbiol. 34:424-432.

He, S. Y. 1998. Type III protein secretion systems in plant and animal pathogenic bacteria. Annu. Rev. Phytopathol. 36:363-392.

Huang, H. C., Schuurink, R., Denny, P. T., Aktinson, M. M., Baker, J. C., Yucel, I., Hutcheson, S. W., and Collmer, A. 1988. Molecular cloning of a Pseudomonas syringae pv. syringae gene cluster that enables Pseudomonas fluorescens to elicit the hypersensitive response in tobacco. J. Bacteriol. 170:4748-4756.
Hugovieux-Cotte-Pattat, N., Dominguez, H., and Robert-Baudouy, J. 1992. Environmental conditions affect transcription of the pectinase genes of Erwinia chrysanthemi 3937. J. Bacteriol. 174:7807-7818.

Huynh, T. V., Dahlbeck, D., and Staskawicz, B. J. 1989. Bacterial blight of soybean: Regulation of a pathogen gene determining host cultivar specificity. Science 245:1374-1377.

Jin, S., Song, Y. N., Deng, W. Y., Gordon, M. P., and Nester, E. W. 1993. The regulatory VirA protein of Agrobacterium tumefaciens does not function at elevated temperatures. J. Bacteriol. 175:6830-6835.

Keane, P. J., Kerr, A., and New, P. B. 1970. Crown gall of stone fruit. II. Identification and nomenclature of Agrobacterium isolates. Aust. J. Biol. Sci. 23:585-595.

Kenton, P., Mur, L. A. J., Atzorn, R., Wasternack, C., and Draper, J. 1999. (-)-Jasmonic acid accumulation in tobacco hypersensitive response lesions. Mol. Plant-Microbe Interact. 12:74-78.

Kenyon, J. S., and Turner, J. G. 1990. Physiological changes in Nicotiana tabacum leaves during development of chlorosis caused by coronatine. Physiol. Mol. Plant Pathol. 37:463-477.

Kenyon, J. S., and Turner, J. G. 1992. The stimulation of ethylene synthesis in Nicotiana tabacum leaves by the phytotoxin coronatine. Plant Physiol. 100:219-224.

King, E. O., Ward, K., and Raney, D. E. 1954. Two simple media for the demonstration of pyocyanin and fluorescein. J. Lab. Clin. Med. 44: 301-307.

Koda, Y., Takahashi, K., Kikuta, Y., Greulich, F., Toshima, H., and Ichihara, A. 1996. Similarities of the biological activities of coronatine and coronafacic acid to those of jasmonic acid. Phytochemistry 41:9396.

Lanham, P. G., McIlravey, K. I., and Perombelon, C. M. 1991. Production of the cell wall dissolving enzyme by Erwinia carotovora subsp. atroseptica in vitro at $27^{\circ} \mathrm{C}$ and $30.5^{\circ} \mathrm{C}$. J. Appl. Bacteriol. 70:20-24.

Liyanage, H., Palmer, D., Ullrich, M., and Bender, C. L. 1995. Characterization and transcriptional analysis of the gene cluster for coronafacic acid, the polyketide compound of the phytotoxin coronatine. Appl. Environ. Microbiol. 61:3843-3848.

Lindgren, P. B. 1997. The role of $h r p$ genes during plant-bacterial interactions. Annu. Rev. Phytopathol. 35:129-152.

Mazzucchi, U., and Rudolph, K. 1984. Inhibition of the hypersensitive reaction in tobacco leaves by extracellular polysaccharides from phytopathogenic pseudomonads. Phytopathol. Z. 111:203-208

Minardi, P. 1995. Altered expression of Erwinia amylovora Hrp genes in tobacco leaves pretreated with bacterial protein-lipopolysaccharides. J. Phytopathol. 143:199-205.

Mino, Y., Matasushita, Y., and Sakai, R. 1987. Effect of coronatine on stomatal opening in leaves of broad bean and Italian ryegrass. Ann. Phytopathol. Soc. Jpn. 53:53-55.

Mitchell, R. E. 1982. Coronatine production by some phytopathogenic pseudomonads. Physiol. Plant Pathol. 20:83-89.

Mitchell, R. E. 1984. A naturally-occurring structural analogue of the phytotoxin coronatine. Phytochemistry 23:791-793.

Mittal, S., and Davis, K. R. 1995. Role of the phytotoxin coronatine in the infection of Arabidopsis thaliana by Pseudomonas syringae pv. tomato. Mol. Plant-Microbe Interact. 1:165-171.

Newman, M.-A., Daniels, M. J., and Dow, J. M. 1997. The activity of lipid A and core components of bacterial lipopolysaccharides in the prevention of the hypersensitive response in pepper. Mol. PlantMicrobe Interact. 7:926-928.

Novacky, A. 1972. Suppression of the bacterially induced hypersensitive reaction by cytokinins. Physiol. Plant Pathol. 2:101-104.

Palmer, D. A., and Bender, C. L. 1993. Effects of environmental and nutritional factors on production of the polyketide phytotoxin coronatine by Pseudomonas syringae pv. glycinea. Appl. Environ. Microbiol. 59:1619-1623.

Palmer, D. A., and Bender, C. L. 1995. Ultrastructure of tomato leaf tissue treated with the pseudomonad phytotoxin coronatine and comparison with methyl jasmonate. Mol. Plant-Microbe Interact. 8:683692.

Penaloza-Vazquez, A., and Bender, C. L. 1998. Characterization of CorR, a transcriptional activator which is required for biosynthesis of the phytotoxin coronatine. J. Bacteriol. 180:6252-6259.

Rangaswamy, V., Jiralerspong, S., Parry, R., and Bender, C. L. 1998a. Biosynthesis of the Pseudomonas polyketide coronafacic acid requires monofunctional and multifunctional polyketide synthase proteins. Proc. Natl. Acad. Sci. USA 95:15469-15474. 
Rangaswamy, V., Mitchell, R. E., Ullrich, M., and Bender, C. L. 1998b. Analysis of genes involved in biosynthesis of coronafacic acid, the polyketide component of the phytotoxin coronatine. J. Bacteriol. 180: 3330-3338.

Reymond, P., and Farmer, E. E. 1998. Jasmonate and salicylate as global signals for defense gene expression. Curr. Opin. Plant Biol. 1:404 411.

Rickauer, M., Brodschelm, W., Bottin, A., Veronesi, C., Grimal, H., and Esquerre-Tugaye, M. T. 1997. The jasmonate pathway is involved differentially in the regulation of different defence responses in tobacco cells. Planta 202:155-162.

Robinette, D., and Matthysse, A. G. 1990. Inhibition by Agrobacterium tumefaciens and Pseudomonas savastanoi of development of the hypersensitive response elicited by Pseudomonas syringae pv. phaseolicola. J. Bacteriol. 172:5742-5749.

Rose, E., and Rudolph, K. 1976. Einfluß des Pseudomonas phaseolicola-Toxins auf die Hypersensitivitätsreaktion von Tabak gegenüber Pseudomonas lachrymans und anderen Pseudomonaden. Phytopathol. Z. 87:241-254.

Rowley, K. B., Clements, D. E., Mandel, M., Humphreys, T., and Patil, S. S. 1993. Multiple copies of a DNA sequence from Pseudomonas syringae pathovar phaseolicola abolish thermoregulation of phaseolotoxin production. Mol. Microbiol. 8:625-635.

Sakai, R. 1980. Comparison of physiological activities between coronatine and indole-3-acetic acid to some plant tissues. Ann. Phytopathol. Soc. Jpn. 46:499-503.

Sakai, R., Nishiyama, K., Ichihara, A., Shiraishi, K., and Sakamura, S. 1979. Studies on the mechanism of physiological activity of coronatine: Effect of coronatine on cell wall extensibility and expansion of potato tuber tissue. Ann. Phytopathol. Soc. Jpn. 45:645-653.

Sambrook, J., Fritsch, E. F., and Maniatis, T. A. 1989. Molecular Cloning: A Laboratory Manual, 2nd ed. Cold Spring Harbor Laboratory, Cold Spring Harbor, NY.

Schüler, G., Wasternack, C., and Boland, W. 1999. Synthesis of 6-azido1-oxo-indan-4-oyl isoleucine; a photoaffinity approach to plant signaling. Tetrahedron 55:3897-3904.

Sembdner, G., and Parthier, B. 1993. The biochemistry and the physiological and molecular actions of jasmonate. Annu. Rev. Plant Physiol. Plant Mol. Biol. 44:569-589.

Tamura, K., Zhu, Y., Sato, M., Teraoka, T., Hosokawa, D., and Watanabe
M. 1998. Roles of coronatine production by Pseudomonas syringae pv. maculicola for pathogenicity. Ann. Phytopathol. Soc. Jpn. 64:299302.

Ullrich, M., and Bender, C. L. 1994. The biosynthetic gene cluster for coronamic acid, an ethylcyclopropyl amino acid, contains genes homologous to amino acid-activating enzymes and thioesterases. J. Bacteriol. 176:7574-7586.

Ullrich, M., Guenzi, A. C., Mitchell, R. E., and Bender, C. L. 1994. Cloning and expression of genes required for coronamic acid (2-ethyl1-aminocyclopropane-1-carboxylic acid), an intermediate in the biosynthesis of the phytotoxin coronatine. Appl. Environ. Microbiol. 60: 2890-2897.

Ullrich, M., Penaloza-Vazquez, A., Bailey, A. M., and Bender, C. L. 1995. A modified two-component regulatory system is involved in temperature-dependent biosynthesis of the Pseudomonas syringae phytotoxin coronatine. J. Bacteriol. 177:6160-6169.

Veronesi, C., Rickauer, M., Fournier, J., Pouenat, M., and EsquerreTugaye, M. T. 1996. Lipoxygenase gene expression in the tobaccoPhytophthora parasitica nicotianae interaction. Plant Physiol. 112: 997-1004.

Wacek, T. J., and Sequeira, L. 1973. The peptidoglycan of Pseudomonas solanacearum: Chemical composition and biological activity in relation to the hypersensitive reaction in tobacco. Physiol. Plant Pathol. 3:363-369.

Wang, L., Bender, C. L., and Ullrich, M. S. 1999. The transcriptional activator CorR is involved in biosynthesis of the phytotoxin coronatine and binds to the cmaABT promoter region in a temperaturedependent manner. Mol. Gen. Genet. 262:250-260.

Weiler, E. W. 1997. Octadecanoid-mediated signal transduction in higher plants. Naturwissenschaften 84:340-349.

Weiler, E. W., Kutchan, T. M., Gorba, T., Brodschelm, W., Niesel, U., and Bublitz, F. 1994. The Pseudomonas phytotoxin coronatine mimics octadecanoid signalling molecules of higher plants. FEBS Lett. 345:9-13.

Wiebe, W. L., and Campbell, R. N. 1993. Characterization of Pseudomonas syringae pv. maculicola and comparison with $P$. s. tomato. Plant Dis. 77:414-419.

Zhang, Z. P., Krumm, T., and Baldwin, I. T. 1997. Structural requirements of jasmonates and mimics for nicotine induction in Nicotiana sylvestris. J. Chem. Ecol. 23:2777-2789. 